\title{
New Records of Diatoms (Bacillariales, Rhopalodiales \& Surirellales) with Ultrastructure Details from the Black Sea Coast of Turkey
}

\author{
Seher Dirican ${ }^{1}$ (D), Aydın Kaleli² (D), Elif Yılmaz ${ }^{3}$ (D), Ali Özer ${ }^{4}$ (D) Hayri Dayıoğlu ${ }^{3}$ (D) \\ Cite this article as: Dirican, S., Kaleli, A., Yilmaz, E., Ozer, A., \& Dayioglu, H. (2022). New records of diatoms (Bacillariales, Rhopalodiales \& Surirellales) \\ with Ultrastructure Details from the Black Sea coast of Turkey. Aquatic Sciences and Engineering, 37(1), 19-28.
}

\section{ORCID IDs of the author: \\ A.K. 0000-0003-3843-1335; \\ S.D. 0000-0001-9130-5114; \\ E.Y. 0000-0002-7814-3429; \\ A.Ö. 0000-0002-4207-8207 \\ H.D. 0000-0002-5233-4024}

${ }^{1}$ Sivas Cumhuriyet University, Vocational School of Sivas, Department of Crop and Animal Production, Sivas, Turkey ${ }^{2}$ Istanbul University, Faculty of Aquatic Sciences, Department of Marine and Freshwater Resources Management, Istanbul, Turkey

${ }^{3}$ Kütahya Dumlupınar University, Faculty of Arts and Sciences, Department of Biology, Kütahya, Turkey

${ }^{4}$ Sivas Cumhuriyet University, Faculty of Engineering, Department of Metallurgical and Materials Engineering, Sivas, Turkey

Submitted:

16.08.2021

Revision Requested:

24.10.2021

Last Revision Received:

26.10.2021

Accepted:

26.10.2021

Online Published:

31.12.2021

Correspondence:

Aydın Kaleli

E-mail:

aydin.kaleli@istanbul.edu.tr

\section{ABSTRACT}

Diatoms associated with the order Bacillariales, Rhopalodiales and Surirellales are well known to be present in marine and brackish waters. In this study, diatoms in the western Black Sea coasts of Turkey were investigated with ultrastructure details. Species belonging to the Bacillariales, Rhopalodiales and Surirellales were subject to light microscopy (LM) and scanning electron microscopy (SEM) analysis, and a total of twenty-four taxa were investigated. This study examines details on the morphology and biogeography of the taxa with remarks on their distribution in Turkey. The results revealed that four species were reported on the Turkish coasts for the first time. These species were Nitzschia liebethruthii, N. volvendirostrata, Epithemia guettingeri and Campylodiscus scalaris.

Keywords: Bacillariophyceae, biodiversity, diatoms, scanning electron microscopy, the Black Sea

\section{INTRODUCTION}

Diatoms make essential contributions to primary productivity and the photosynthesis rate (Salleh \& McMinn, 2011; Witkowski, Bohaty, Edgar \& Harwood, 2014). Benthic diatom taxonomy studies determine the flora of the observed area and are useful for further research, e.g. ecology and monitoring. The Black Sea has brackish water characteristics like the Baltic Sea and the Caspian Sea. Unlike the Caspian Sea, the Black Sea and Baltic Sea show some morphological similarities. The Baltic Sea is connected to the North Sea via the Kiel strait; the Black Sea is connected to the Mediterranean via the Dardanelles and the Bosphorus straits; however, water flow is relatively lower. The low rate of saline water flowing through the straits to the Black Sea is one reason for this habitat to show brackish characteristics. However, it has a high rate of river discharge along its coasts. Compared to waters with similar characteristics, the Baltic Sea has been the most studied in recent years. Diatom distribution in the Baltic Sea has been studied by several researchers
(Witkowski, 1991; Vilbaste, Sundback, Nilsson \& Truu, 2000; Hällfors, 2004).

There have been several studies in marine habitats from the Black Sea. One of the pioneering studies was performed by Mereschkowsky (1902) and Proshkina-Lavrenko (1955, 1963). However, in the last decade, there have been more papers published on the composition and distribution of diatoms of the Black Sea. Most of these studies were performed in the northern part of the Black Sea (Petrov, Nevrova, Terletskaya, Milyukin \& Demchenko, 2010; Nevrova, Witkowski, Kulikovskiy, Lange-Bertalot \& Kociolek, 2013; Snigireva \& Kovaleva, 2015; Nevrova, 2016). Along the southern coasts, studies were limited to a few published papers (Baytut, Gönülol \& Koray, 2005; Kaleli, Kulikovskiy \& Solak, 2017).

The latest studies reported significant numbers of diatom taxa in the southern Black Sea. However, there is still insufficient data. The diatom flora of the Baltic Sea is an example of taxa that can be used as a comparison for the south 
Black Sea. Nevertheless, brackish species have been a challenge for researchers in the past. Some taxa may be confused as being marine, brackish or even as a freshwater species. Monographs, including the brackish taxa (Krammer \& Lange-Bertalot, 1988; Witkowski, Lange-Bertalot \& Metzeltin, 2000; Hofmann, Werum \& Lange-Bertatlot, 2011) are good ways of identifying these taxa. According to some authors, certain environmental parameters (e.g., salinity, temperature) are necessary to identify the taxa. UItrastructural studies can contribute to the knowledge of the diatom structure in the observed area, even though data is lacking in the Black Sea apart from a few studies in the north (Witkowski, Kulikovskiy, Nevrova, Lange-Bertalot \& Gogorev, 2010; Nevrova et al., 2013; Nevrova \& Petrov, 2019). When compared to the illustrated fine structure of the freshwater diatoms, marine diatoms have slightly less available data.

Members of the Bacillariaceae family have the highest number of taxa with the Naviculaceae (Kociolek et al., 2021); Nitzschia, Rhopalodia, and Surirella making up many brackish taxa. These brackish conditions, e.g. low saline coasts or electrolyte-high waters, can show high biodiversity. Therefore, diatoms from the Bacillariaceae family are of interest in this paper. Here we present some Bacillarioideae diatoms through the fine structure from the Black Sea coast of Ereğli and report 24 taxa from the Nitzschia, Surirella, Rhopalodia, Tryblionella, and Psammodictyon genera. This paper focuses on the species which are known to be found in marine-brackish waters. This paper discusses taxa on morphology data provided with Scanning electron microscopy (SEM) analysis and comments on their biogeography.

\section{MATERIAL AND METHODS}

Ereğli Bay in Zonguldak province is one of the important industrial zones on Turkey's Black Sea coast. The material used in this

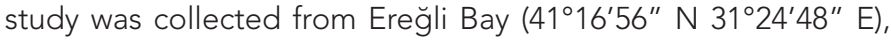
during benthic marine diatom sampling of the Black Sea coasts in August 2017 (Fig. 1). Sampling was performed by scraping the submerged stones and rocks at the port.

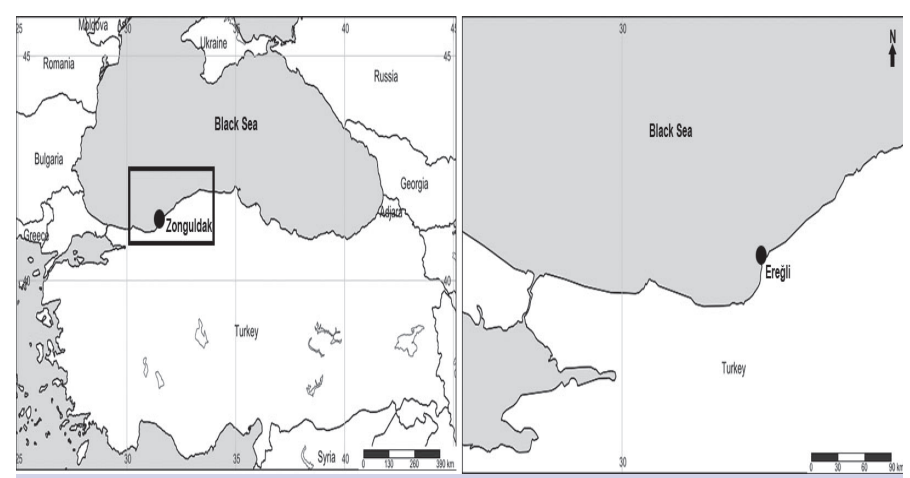

Figure 1. Sampling site location, Ereğli, Zonguldak province, Turkey.

Samples were treated with $10 \% \mathrm{HCl}$, then with $\mathrm{H}_{2} \mathrm{O}_{2}$ to remove the organic material and were then washed with distilled water four times. Permanent slides were prepared with air-dried clean valves and mounted with Naphrax®. Observations in the light micro- scope (LM) were performed with an Olympus BX-51 microscope at Kütahya Dumlupınar University. SEM observations were performed by Tescan Mira3 XMU at the Sivas Cumhuriyet University Advanced Technology Application and Research Center. Valve measurements were made using ImageJ software. Taxonomic classification and nomenclatural updates followed that of Maraşlığlu \& Gönülol (2021), Guiry \& Guiry (2021) and Kociolek et al., (2021).

\section{RESULTS AND DISCUSSION}

\section{Bacillariales Hendey Cylindrotheca Rabenhorst}

\section{Cylindrotheca closterium (Ehrenberg) Reimann \& Lewin} Fig. 4: 26, 27

Basionym: Ceratoneis closterium Ehrenberg

Synonym(s): Ceratoneis closterium Ehrenberg, Nitzschiella curvirostris var. closterium (Ehrenberg) De Toni, Nitzschia longissima var. closterium (Ehrenberg) Peragallo \& Peragallo, Nitzschiella tenuirostris Mereschkowsky.

References: Hasle \& Syvertsen (1996)

Dimensions: Length $52 \mu \mathrm{m}$, width $3.9 \mu \mathrm{m}$.

Remarks: Cylindrotheca closterium was found to be cosmopolitan in marine phytoplankton. The species is also known to be harmful algae (Hasle \& Syvertsen, 1996).

Distribution \& biogeography: The taxon was identified in different locations in Turkey (Maraşlıoğlu \& Gönülol, 2021), it is a cosmopolitan and widespread species of marine coasts (Guiry \& Guiry, 2021).

\section{Nitzschia Hassall}

Nitzschia amabilis $\mathrm{H}$. Suzuki

Fig. 3: 16-19

Synonym: Nitzschia laevis Hustedt 1939

References: Witkowski et al. (2000), Suzuki et al. (2010)

Dimensions: Length 10-12.1 $\mu \mathrm{m}$, width 4.6-4.9 $\mu \mathrm{m}$, striae 38-40 in $10 \mu \mathrm{m}$, costae $14-16$ in $10 \mu \mathrm{m}$.

Remarks: Valves are elliptic, the median fibula is distinct, internally the raphe is slightly undulated, terminal raphe endings extend to the apices. In external valves, hymenes were observed internally.

Distribution \& biogeography: Hustedt (1939) identified taxa from the coasts of Germany as Nitzschia laevis (non N. laevis Frenguelli). It is a widespread species (Guiry \& Guiry, 2021) and has been reported and documented on the Aegean coast of Turkey (Kaleli, et al., 2020).

Nitzschia incognita Legler \& Krasske

Fig. 2: 4

References: Legler \& Krasske (1940), Witkowski et al. (2000).

Dimensions: Length $48 \mu \mathrm{m}$, width $3 \mu \mathrm{m}$, costae 12 in $10 \mu \mathrm{m}$. 


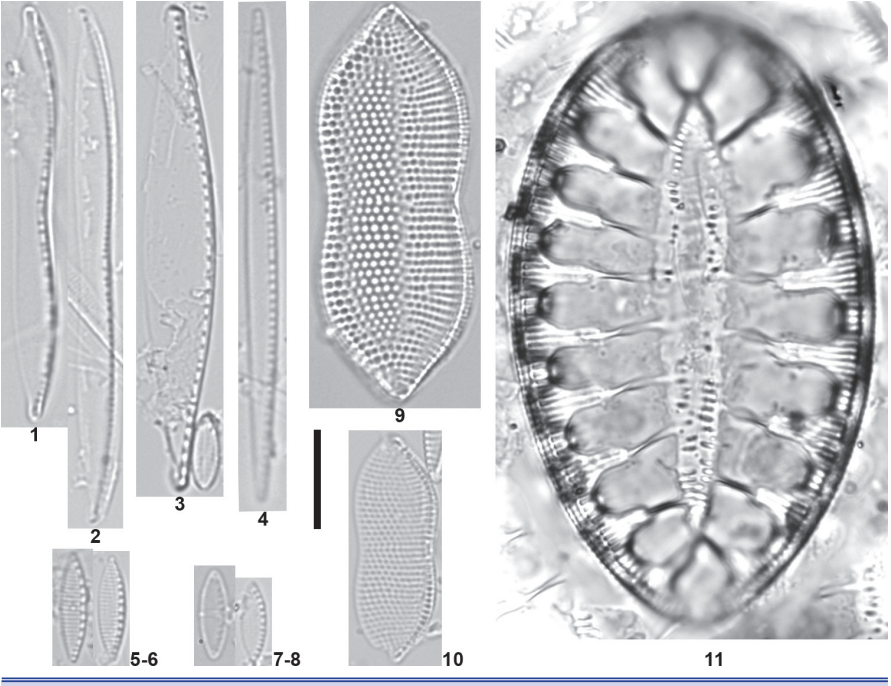

Figure 2. Scale bar: $10 \mu \mathrm{m} .1$, 2. Nitzschia cf. traheaformis; 3. N. lanceolata, 4. N. incognita, 5, 6. N. liebethruthii; 7,8. N. inconspicua, 9. Psammodictyon panduriforme var. continuum; 10. Tryblionella coarctata, 11. Surirella fastuosa. Scale bar: $10 \mu \mathrm{m}$.

Remarks: Striae are indiscernible in LM, median distant fibula exist, valve endings are narrowed apiculate.

Distribution \& biogeography: Nitzschia incognita is a brackish water species that was identified in Lake Van, Turkey (Legler \& Krasske, 1940), and observed in the temperate waters of Europe (Guiry \& Guiry, 2021) and the Mediterranean Sea (Witkowski et al., 2000).

\section{Nitzschia inconspicua Grunow Fig. 2: 7, 8}

Synonym(s): Nitzschia frustulum var. inconspicua (Grunow) Grunow, Homoeocladia inconspicua (Grunow) Kuntze, Nitzschia perpusilla var. inconspicua Grunow

References: Rovira et al (2015).

Dimensions: Length 7.2-12.5 $\mu \mathrm{m}$, width 2.3-2.9 $\mu \mathrm{m}$, costae 14-20 in $10 \mu \mathrm{m}$.

Remarks: The taxon resembles N. frustulum; however, transapical striae are indistinct in LM, and the valves are broader-lanceolate than the former taxa. It is a widespread brackish-freshwater species (Guiry \& Guiry, 2021).

Distribution \& biogeography: Species was reported and documented from the Aegean streams and is also common in Turkey (Maraşlıoğlu \& Gönülol, 2021). Nitzschia inconspicua is a widespread freshwater species also occurring in brackish water (Guiry \& Guiry, 2021).

\section{Nitzschia lanceolata W. Smith}

Fig. 2: 3

Synonym: Homoeocladia lanceolata (W. Smith) Kuntze

References: Witkowski et al (2000).
Dimensions: Length $47.5 \mu \mathrm{m}$, width $7.1 \mu \mathrm{m}$, costae 8 in $10 \mu \mathrm{m}$.

Remarks: One valve of Nitzschia lanceolata was observed. Valves are broadly lanceolate; fibulae are unevenly distributed.

Distribution \& biogeography: Nitzschia lanceolata was identified in streams in the Aegean and the Black Sea region; however, the taxon was not documented before in marine coasts of Turkey. It is a cosmopolitan marine-brackish species that was reported in the Mediterranean and the Black Sea (Witkowski et al., 2000; Guiry \& Guiry, 2021).

Nitzschia liebethruthii Rabenhorst

Fig. 2: 5, 6; Fig. 3: 15

Synonym: Homoeocladia liebethruthii (Rabenhorst) Kuntze

References: Krammer \& Lange-Bertalot (1988); Witkowski et al. (2000).

Dimensions: Length 11.4-12.4 $\mu \mathrm{m}$, width $2.7 \mu \mathrm{m}$, fibulae 16-18 in $10 \mu \mathrm{m}$.

Remarks: Valves are lanceolate, striae are distinct in LM. N. liebethruthii valves were observed with higher fibulae density (Witkowski et al., 2000; 11-12 in $10 \mu \mathrm{m}$ ). The taxon is close to $\mathrm{N}$. frustulum, and small valves resemble $N$. inconspicua.

Distribution \& biogeography: The species was reported inland of the Antalya and Euphrates regions. This is the first time the species was identified in Turkish coasts. It is a cosmopolitan species
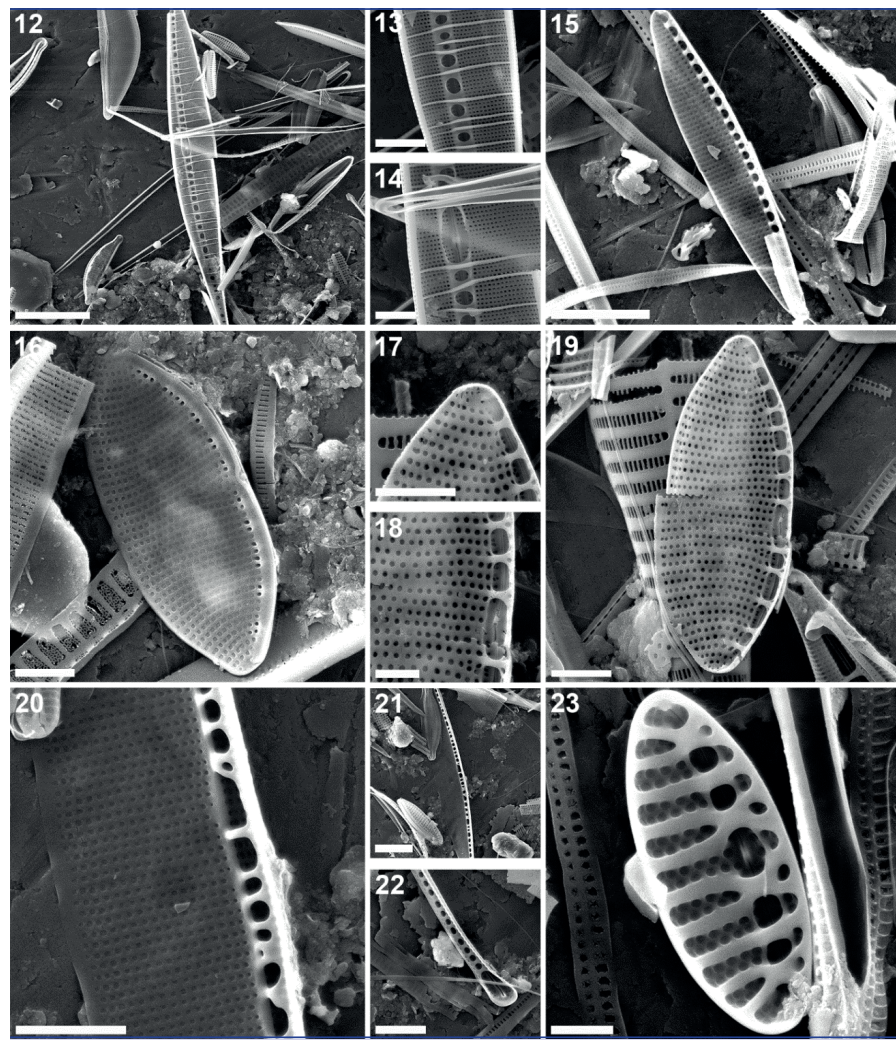

Figure 3. 12-14. Nitzschia ventricosa; 15. N. liebethruthii; 1619. N. amabilis; 20-22. N. reversa; 23. N. valdestriata. Scale bars: 17,18,23: $1 \mu \mathrm{m}$; 13,14,16,20,22: $2 \mu \mathrm{m}$; 15,19,21: $5 \mu \mathrm{m}$; 12: $10 \mu \mathrm{m}$. 
reported in the Mediterranean Sea (Witkowski et al., 2000) and also occurs in brackish-freshwater habitats (Guiry \& Guiry, 2021).

Nitzschia cf. traheaformis Chunlian Li, Witkowski \& Yu Fig. 2: 1, 2; Fig. 4: 30

References: Witkowski et al. (2016).

Dimensions: Length 28.7-36.3 $\mu \mathrm{m}$, width 3.6-3.9 $\mu \mathrm{m}$, striae 34-40 in $10 \mu \mathrm{m}$.

Remarks: Valves are slightly constricted in the middle with apiculate apices. Specimens are similar in valve outline to the following species; however, observed specimens were smaller in size compared to N. hybrida (48-103 $\mu \mathrm{m})$ and N. pellucida (55-70 $\mu \mathrm{m}$; Witkowski et al., 2000). The valves showed more resemblance to $N$. traheaformis, which was 17-54 $\mu \mathrm{m}$ long and 3-4.7 $\mu \mathrm{m}$ wide (Witkowski et al., 2016), and more dubiatae than the other species. Here the valves have higher striae than N. traheaformis (3234 in $10 \mu \mathrm{m}$ ). Therefore we commit the taxa as $N$. cf. traheaformis for further observation.

Distribution \& biogeography: Nitzschia traheaformis was found in the Red and Yellow Sea and the Indian Ocean. It is necessary to observe the taxon in the Black Sea in detail to confirm before addressing and expanding its biogeography.

\section{Nitzschia reversa Smith Fig. 3: 20-22}

Synonym: Nitzschia longissima var. reversa Grunow

References: Snoeijs \& Potapova (1995), Witkowski et al. (2000).

Dimensions: Length $89.8 \mu \mathrm{m}$, width $4.2 \mu \mathrm{m}$, striae 52 in $10 \mu \mathrm{m}$, costae 16 in $10 \mu \mathrm{m}$.

Remarks: Nitzschia reversa can be distinguished by its apices which deflect in opposite directions. It is a cosmopolitan species, found in phytoplankton, identified in inland saline waters (Witkowski et al., 2000; Kociolek et al., 2021).

Distribution \& biogeography: The taxon was identified by ErsanIı \& Gönülol (2003) in Simenit Lake; however, this is the first time it was documented in Turkish coasts. It is cosmopolitan and widespread (Guiry \& Guiry, 2021), found in marine phytoplankton (Witkowski et al., 2000).

\section{Nitzschia ventricosa Kitton}

Fig. 3: 12-14

Synonym: Homoeocladia ventricosa (Kitton) Kuntze

References: Witkowski et al. (2000), Lobban et al. (2012).

Dimensions: Length $160.6 \mu \mathrm{m}$, width $6 \mu \mathrm{m}$, striae 48 in $10 \mu \mathrm{m}$, fibulae 8 in $10 \mu \mathrm{m}$.

Remarks: Valve is long with rostrate endings, fibulae and costae are irregular, central nodule exits, central raphe endings form helictoglossae.

Distribution \& biogeography: This is the first time this species was observed in the coasts of the Sea of Marmara in Turkey (in print). Species is widespread in the warm waters of the oceans and observed in the Mediterranean Sea (Guiry \& Guiry, 2021).

Nitzschia vidovichii (Grunow) Grunow

Fig. 4: 24, 25

Basionym: Homoeocladia vidovichii Grunow

References: Navarro (1982), Navarro \& Lobban (2009).

Dimensions: Length $103.8 \mu \mathrm{m}$, width $7.6 \mu \mathrm{m}$, striae 28 in $10 \mu \mathrm{m}$.

Remarks: The specimen observed here conforms with the micrographs of Navarro (1982), Navarro \& Lobban (2009). Taxon resembles Nitzschia scalpelliformis, showing similar dimensions; however, raphe is centrally formed.

Distribution \& biogeography: It is a widespread marine species (Guiry \& Guiry, 2021). Species was reported from Homa Lagoon in the Aegean Sea (Çolak-Sabancı \& Koray, 2010).

\section{Nitzschia volvendirostrata Ashworth, Dabek \& Witkowski Fig. 4: 28}

References: Witkowski et al. (2016).

Dimensions: Length $12.1 \mu \mathrm{m}$, width $2.8 \mu \mathrm{m}$, striae 52 in $10 \mu \mathrm{m}$, costae 10 in $10 \mu \mathrm{m}$

Remarks: Valve has a linear outline and rostrate apices, fibulae irregular. The taxon resembles Nitzschia nanodissipata, in terms of its outline. Witkowski et al. (2016) described the species with the dimensions of 7-11.5 $\mu \mathrm{m}$ length and 3-3.5 $\mu \mathrm{m}$ width. Here, valve dimensions are slightly higher and resemble $N$. volvendirostrata (striae 52-54 in $10 \mu \mathrm{m}, 8-9$ costae in $10 \mu \mathrm{m}$ ) in terms of striae numbers.

Distribution \& biogeography: Taxon was identified in the Red Sea (Witkowski et al., 2016). This is the first time it has been identified in Turkish coastal waters.

\section{Psammodictyon D.G. Mann}

Psammodictyon panduriforme var. continuum (Grunow) Snoeijs Fig. 2: 9

Basionym: Nitzschia panduriformis var. continua Grunow

Synonym: Nitzschia panduriformis var. continua Grunow

References: Krammer \& Lange-Bertalot (1988), Snoeijs \& Balashova (1998).

Dimensions: Length 18.5-22.5 $\mu \mathrm{m}$, width 7.5-8 $\mu \mathrm{m}$, striae 18-19 in $10 \mu \mathrm{m}$.

Remarks: Taxon is slightly panduriform, valves are smaller than Tryblionella coarctata and have higher striae numbers in the observed material.

Distribution \& biogeography: It is a brackish-marine waters species identified in the Baltic Sea (Snoeijs \& Balashova, 1998). Species was formerly observed in the Aegean Sea coasts in Turkey (Kaleli et al., 2020). 


\section{Tryblionella W. Smith}

Tryblionella compressa (Bailey) Poulin

Fig. 4: 32, 33

Basionym: Pyxidicula compressa Bailey

Synonym(s): Pyxidicula compressa Bailey, Dinopyxis compressa (Bailey) Stein, Exuviaella compressa (Bailey) Ostenfeld, Nitzschia compressa (Bailey) C.S. Boyer, Prorocentrum compressum (Bailey) T.H. Abé ex J.D. Dodge.

References: Poulin et al. (1990), Witkowski et al. (2000), Witon \& Witkowski (2006).

Dimensions: Length $33.1 \mu \mathrm{m}$, width $21.9 \mu \mathrm{m}$, striae 9 in $10 \mu \mathrm{m}$.

Remarks: Valve is lanceolate, slightly inflated in the middle, with produced apices. Striae are punctate and equal to fibulae numbers.

Distribution \& biogeography: Tryblionella compressa is a marine, brackish species and widespread on the coasts (Guiry \& Guiry, 2021).

\section{Tryblionella coarctata (Grunow) Mann}

Fig. 2: 10

Basionym: Nitzschia coarctata Grunow

Synonym(s): Nitzschia coarctata Grunow, Homoeocladia coarctata (Grunow) Kuntze, Nitzschia punctata var. coarctata (Grunow) Hustedt

References: Snoeijs \& Balashova (1998), Witkowski et al. (2000).

Dimensions: Length 31.6-40 $\mu \mathrm{m}$, width $14-15 \mu \mathrm{m}$, striae 12 in 10 $\mu \mathrm{m}$.

Remarks: Valves are panduriform with apiculate endings. Tryblionella coarctata possess punctate aerolation similar to Psammodictyon. Furthermore, $T$. coarctata differs from $P$. panduriforme var. continuum, by the hyaline valve face in one half of the valve in LM micrographs. Also, P. panduriforme var. continuum has lower striae density.

Distribution \& biogeography: It is a cosmopolitan species inhabiting marine (Guiry \& Guiry, 2021) and brackish waters (Snoeijs \& Balashova 1998). It was formerly reported from the Mediterranean Sea (Witkowski et al., 2000) and the Dardanelles Strait (Yıldız, 2018).

Tryblionella cf. coarctata var. densestriata Álvarez-Blanco \& S. Blanco Fig. 4: 31

References: Blanco \& Blanco (2014).

Dimensions: Length $10.7 \mu \mathrm{m}$, width, $5.1 \mu \mathrm{m}$, striae 34 in $10 \mu \mathrm{m}$.

Remarks: One small specimen was observed, the valve is slightly panduriform with a higher striae count (Blanco \& Blanco, 2014; 22-30 in $10 \mu \mathrm{m})$. Blanco \& Blanco (2014) listed the striae numbers from different authors, and here the specimen was closer to the valves observed from Murcia.

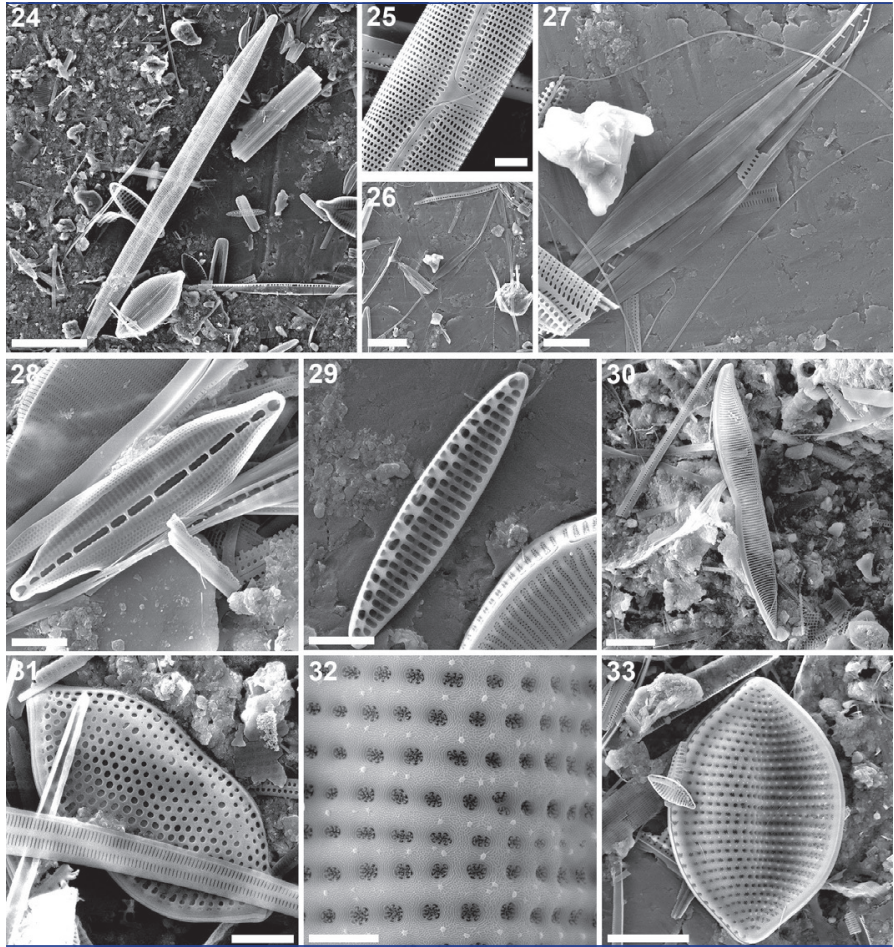

Figure 4. 24, 25. Nitzschia vidovichii; 26, 27 Cylindrotheca closterium; 28. Nitzschia volvendirostrata; 29. Nitzschia. sp.1; 30. N. cf. traheiformis; 31. Tryblionella cf. coarctata var. densestriata; 32, 33. Tryblionella compressa. Scale bars: 25,27,28,29,31,32: 2 нm; 30: 5 $\mu \mathrm{m} ; 24,26,33: 10 \mu \mathrm{m}$.

Distribution \& biogeography: Taxon was described in the Mediterranean Sea (Blanco \& Blanco, 2014).

\section{Rhopalodiales D.G. Mann}

\section{Protokeelia C.W. Reimer \& J.J. Lee}

\section{Protokeelia sp. Fig. 5: 36, 43}

Dimensions: Length 7.2-11.2 $\mu \mathrm{m}$, width 2.5-3.5 $\mu \mathrm{m}$, striae 32-36 in $10 \mu \mathrm{m}, 35$ coastae in $10 \mu \mathrm{m}$.

Remarks: Valves are semi lunate to weakly convex and some valves are constricted slightly in the middle, almost straight at the ventral margin. Valve endings are acute and rounded, not produced, areolation are biseriate, raphe terminates slightly before the apices, and is expanded. Central endings are near, slightly bent on the dorsal side in the external valve. In the internal view, fibulae are regular and rounded. Central median fibulae exist with an open gap, however, just one valve was observed and more valves might reveal if it is an opening or broken part of the fibulae. The ventral margin girdle band is placed with two rows oblong of areolae. Taxa resemble genus Protokeelia with its characteristics. Some differences were found though, like the ventral side of the specimens resemble mostly $P$. hottingeri $(R e-$ imer \& Lee, 1984; Lee et al., 1989); the structure of the keel and biseriate areolae are similar, although fibulae structure are different, or ventral margin of $P$. spinifera, $P$. aculeata and $P$. cholnokyii 
are concave (Round \& Basson, 1995a,b), while Protokeelia sp. has straight margins. Therefore we commit the taxa to Protokeelia sp. for further studies.

\section{Epithemia Kützing}

Epithemia guettingeri (Krammer) Lobban \& J.S. Park Fig. 5: 37-39

References: Krammer (1988), Park et al. (2018)

Dimensions: Length 19.9-26.5 $\mu \mathrm{m}$, width 8-8.3 $\mu \mathrm{m}, 40$ striae in 10 $\mu \mathrm{m}, 11-16$ costae in $10 \mu \mathrm{m}$.

Remarks: Valves are dorsiventral, and straight at the ventral margin. Apices are acute and rounded, raphe terminates at the apices. Central endings are bent on the dorsal side of the valve. Costae are regularly distributed, and striae are biseriate. In the specimens, flabelli-like structure was observed on the areolae. Fibulae are irregular, and median central raphe was observed. Apical costae in the middle of the valve were observed in the external valve view; however, in the internal view, it was not observed, which is in line with Krammer (1988). Park et al. (2018) indicated Epithemia guettingeri and E. pacifica resemble, and the median costae differs, both existed and were observed in internal and external valves in E. guettingeri, while in E. pacifica it was observed in the internal valve. Here, areolae presence on the apical band conforms with SEM images of Park et al. (2018). Taxon has recently been proposed to be transferred back to the genus Epithemia (Park et al., 2018).

Distribution \& biogeography: It is a marine species which was reported in temperate waters of the oceans (Guiry \& Guiry 2021). It is reported for the first time in the Turkish coasts.

Epithemia pacifica (Krammer) Lobban \& J.S. Park Fig. 5: 40-42

References: Lange-Bertalot \& Krammer (1987), Witkowski et al. (2000).

Dimensions: Length $40 \mu \mathrm{m}$, width $8.7 \mu \mathrm{m}$, striae 18 in $10 \mu \mathrm{m}$, costae 8 in $10 \mu \mathrm{m}$.

Remarks: Valve is strongly dorsiventral and slightly concave at the ventral margin. Areolae are circular, striae are biseriate, raphe terminates at the produced rostrate apices. In the fine structure of the broken valve, the median apical hyaline band was observed. Recently taxa were proposed as Epithemia pacifica (Park et al., 2018).

Distribution \& biogeography: It is a marine species described from the Pacific Ocean (Guiry \& Guiry, 2021) and also was observed in the Mediterranean Sea (Hafner et al., 2018). It is observed for the first time in the Sea of Marmara coasts in Turkey (in print).

\section{Rhopalodia O. Müller}

\section{Rhopalodia cf. brebissonii Krammer}

Fig. 5: 34, 35

References: Lange-Bertalot \& Krammer (1987), Witkowski et al. (2000).
Dimensions: Length $19 \mu \mathrm{m}$, width $4.3 \mu \mathrm{m}, 30$ striae in $10 \mu \mathrm{m}, 5$ costae in $10 \mu \mathrm{m}$.

Remarks: Valve is dorsally convex, ventrally straight. Areolae are square-oblong, here apices were not produced and acutely apiculate. In Lange-Bertalot \& Krammer (1987) valves have produced endings and are bent at the ventral margin, differed from the specimen observed and striae 30 in $10 \mu \mathrm{m}$ (Lange-Bertalot \& Krammer, 1987; 17-22 in $10 \mu \mathrm{m}$ ) are higher than described. Ruck et al. (2016) proposed the transfer of Rhopalodia species into Epithemia, therefore, after further analysis to confirm specimen belongs to $R$. brebissonii it can be proposed to move into Epithemia.

Distribution \& biogeography: It is a freshwater taxon (Guiry \& Guiry, 2021), reported from the Baltic Sea (Snoeijs \& Balashova, 1998).

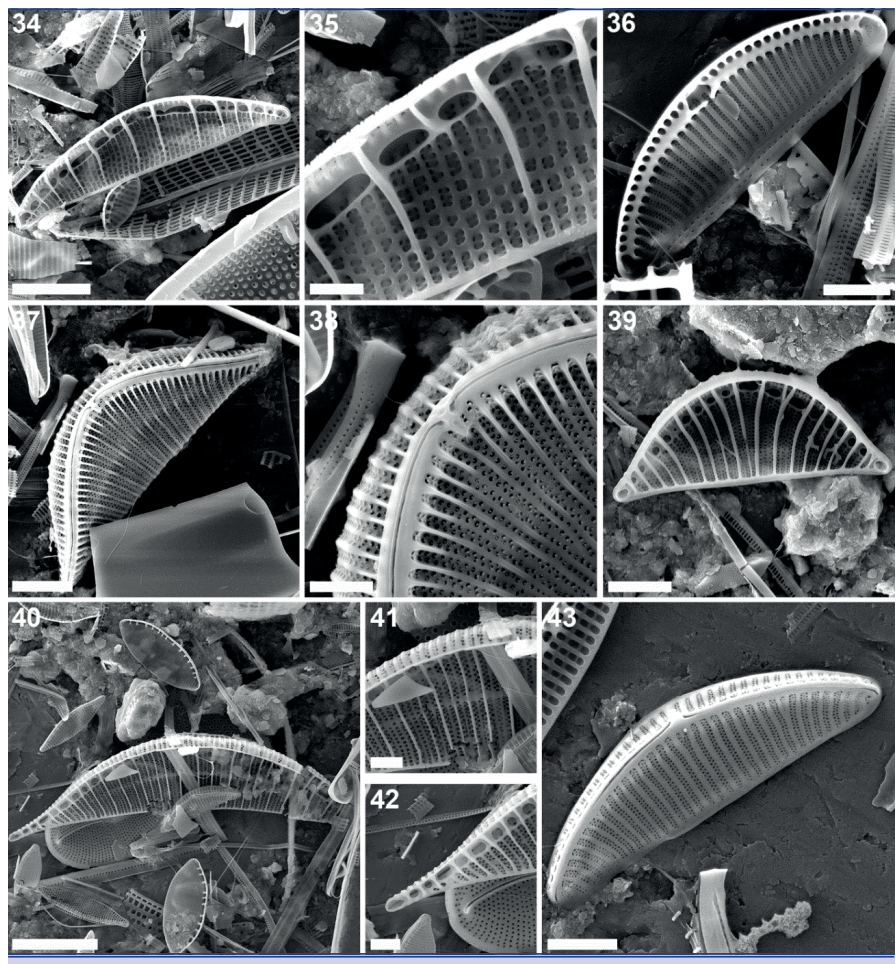

Figure 5. 34, 35. Rhopalodia cf. brebissonii; 36. Protokeelia sp. 1; 37-39. Epithemia guettingeri; 40-42. E. pacifica, 43. Protokeelia sp.1. Scale bars: 34,37,39: $5 \mu \mathrm{m} ; 35: 1$ $\mu \mathrm{m} ; 36,38,41,42,43: 2 \mu \mathrm{m} ; 40: 10 \mu \mathrm{m}$.

\section{Surirellales D.G. Mann}

\section{Campylodiscus Ehrenberg ex Kützing}

Campylodiscus scalaris (Giffen) Lobban \& Park

Fig. 6: 44-46

Basionym: Surirella scalaris Giffen

References: Giffen (1967), Navarro (1983), Lobban et al (2012), Park et al. (2018)

Dimensions: Length $22.2 \mu \mathrm{m}$, width $22 \mu \mathrm{m}$. 
Remarks: SEM images of Campylodiscus scalaris showing that external valve is depressed, the central area is connected to margins by canals, double branched near the margin. In internal view, areolae were small, oblong, and formed a mixed distribution. Warts cover the branches and the occluded area in between. Giffen (1967) described taxa as Surirella scalaris, Lobban et al. (2012) proposed a transfer of the species into Campylodiscus (see, C. scalaris non Tempére \& Brun 1889 for different species).

Distribution \& biogeography: This is the first record for the Turkish flora, reported from the Pacific Ocean and the Adriatic Sea (Guiry \& Guiry, 2021).

\section{Campylodiscus aff. bicostatus W. Smith ex Roper}

Fig. 6: 47

Synonym: Campylodiscus clypeus var. bicostata (W. Smith ex Roper) Hustedt

References: Peragallo \& Peragallo (1897-1908)

Dimensions: Length $22.1 \mu \mathrm{m}$, width $19.3 \mu \mathrm{m}$.

Remarks: Valve consists of a large hyaline area in the centre and irregular punctae are located at the margin between the ribs. Drawings of Peragallo \& Peragallo (1897-1908) and Hustedt (1985) resemble the valve found here. However, more specimens should be observed to dedicate the taxa to C. bicostatus.

Distribution \& biogeography: C. bicostatus was reported from different locations, formerly reported from the Sarıkum lagoon and freshwater lakes (Maraşlıoğlu \& Gönülol, 2021 and references therein). It is a cosmopolitan freshwater species (Guiry \& Guiry, 2021).

\section{Campylodiscus cf. thureti Brébisson}

Fig. 6: 54

References: Romagnoli et al. (2014), Kulikovskiy et al. (2016), Schmidt (1874-1959)

Dimensions: Length $32 \mu \mathrm{m}$, width $24.5 \mu \mathrm{m}$.

Remarks: Valve is oval, composing triseriate striae crossed by ribs and emerges near the margin. Ribs are more further apart, similar to Romagnoli et al. (2014). Our specimen resembles C. cf. thuretii in Romagnoli et al. (2014). Before committing the specimen into $C$. thuretii, more valves should be observed.

Distribution \& biogeography: C. thuretii has not been recorded in Turkey before, it has been reported from the temperate waters of marine coasts (Guiry \& Guiry, 2021) and the Mediterranean Sea (Romagnoli et al., 2014).

\section{Surirella Turpin}

Surirella cf. brebissonii var. kuetzingii Krammer \& Lange-Bertalot Fig. 6: 51-53

References: Krammer \& Lange-Bertalot (1987), Schmidt (18741959).

Dimensions: Length 28.3-34.9 $\mu \mathrm{m}$, width 12.1-13 $\mu \mathrm{m}$, 31striae in $10 \mu \mathrm{m}$.
Remarks: Valves are wedge-shaped and broadly rounded in headpole and narrower and rounded in the foot pole. Striae are parallel to radiate at the endings and biseriate. Taxon resembles Surirella brebissoni var. kuetzingii in terms of its valve outline (Krammer \& Lange-Bertalot, 1987), however in SEM S. brebissonii var. kuetzingii composed triseriate-quadriseriate striae (English \& Potapova, 2011). In LM striae are discernible in the centre of the valve face. Species also resemble S. suevica Zeller (Krammer \& Lange-Bertalot, 1987; fig. 46,47) and Schmidt (18741959; pl.23: 60-65). Further observation is needed from the material.

Distribution \& biogeography: It was reported from different regions of inland waters. (Guiry \& Guiry, 2021).

\section{Surirella fastuosa (Ehrenberg) Kützing} Fig. 2: 11; Fig. 6: 48-50

References: Peragallo \& Peragallo (1897-1908), Witkowski et al. (2000).

Dimensions: Length $60.1 \mu \mathrm{m}$, width $34.9 \mu \mathrm{m}$.

Remarks: Surirella fastousa shows a wide range of valve morphology; valves are elliptic-ovate with rounded apices in general, due to this character taxon is similar to $S$. armoricana in valve outline. Our specimen resembles S. armoricana Peragallo, with wider costae at the margin. Illustrations of Hendey (1974, PI. 40:6) and Foged (1975, PI.30:5) match our specimen; however, the drawings and description of S. armoricana in Peragallo \& Peragallo (1897-1908) revealed that the central area is panduriform. Therefore we commit our specimen to $S$. fastousa.

Distribution \& biogeography: Taxa was reported from temperate waters of the coasts of oceans (Guiry \& Guiry, 2021).

In this study, members of the Bacillariales, Rhopalodiales and Surirellales from the coast of the Black Sea were investigated, which have a more complex structure such as fibula or keel. A total of 24 species were observed and of these, 22 taxa were investigated with fine structure. Taxa were discussed with regards to taxonomy and biogeographical distribution. Fifteen species were observed from the Bacillariales including Cylindrotheca, Nitzschia, Psammodictyon and Tryblionella; while four taxa from the Rhopalodiales showed distribution with Protokeelia, Rhopalodia and finally the Surirellales were composed of five taxa belonged to Campylodiscus, and Surirella. Taxa observed here have marine-brackish habitat preferences. Some taxa (Tryblionella compressa, Surirella cf. brebissonii var. kuetzingii, Rhopalodia cf. brebissonii) presented here showed a wide range of distribution in the coasts and lakes of Turkey (Maraşlığlu \& Gönülol, 2021).

Amongst the species, several of them were formerly reported from the Black Sea, including Cylindrotheca closterium, Nitzschia liebethruthii, N. inconspicua, N. liebethruthii, Psammodictyon panduriforme var. continuum, Surirella fastuosa, Tryblionella compressa and T. coarctata (Nevrova, 2016; Nevrova \& Petrov, 2019). In the Aegean Sea coasts, common species were Campylodiscus scalaris, Epithemia guettingeri, Nitzschia amabilis, N. liebethruthii, N. inconspicua (Louvrou, 2007). Similarly, species 


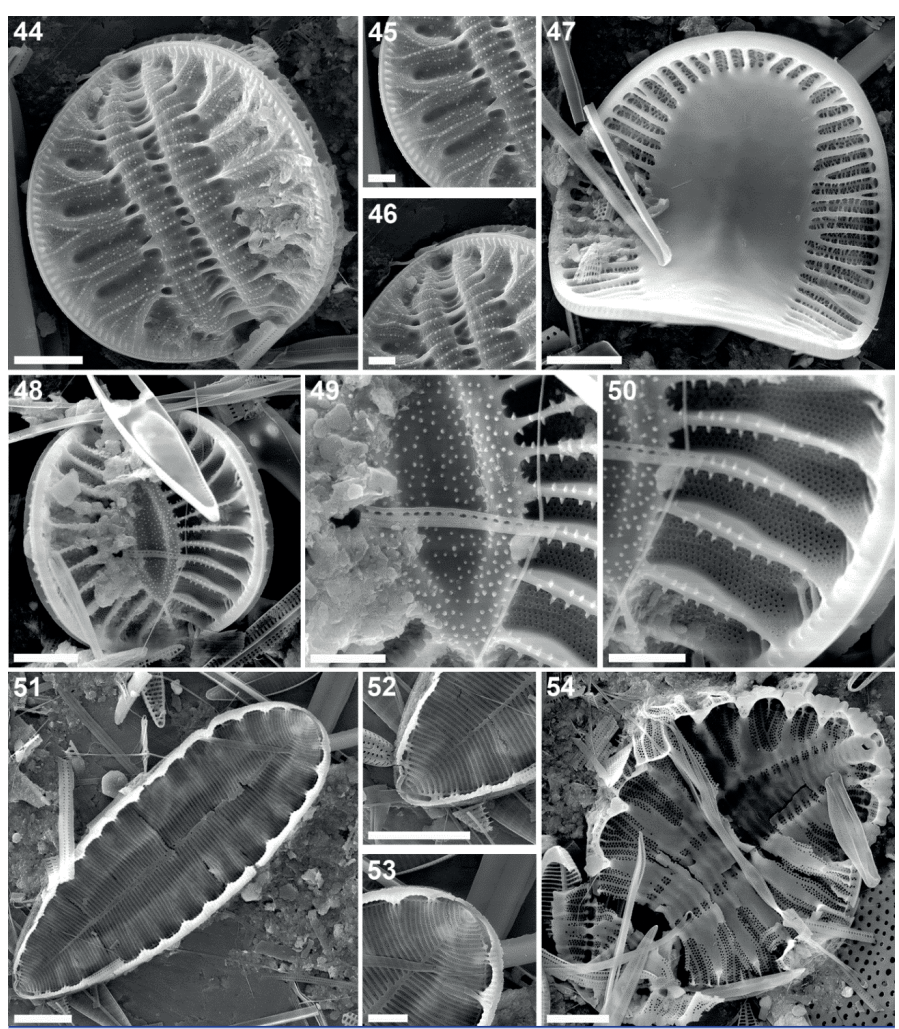

Figure 6. 44-46. Campylodiscus scalaris; 47. C. cf. bicostatus; 48-50. Surirella fastuosa; 51-53. Surirella cf. brebissonii var. kuetzingii; 54. Campylodiscus cf. thuretii. Scale bars: 45,46,49,50,52,53: $2 \mu \mathrm{m}$; $44,47,48,51,54: 5 \mu \mathrm{m}$.

numbers were higher in the lower saline waters of the Black Sea (Nevrova \& Petrov, 2019). While marine diatom ecology has been given less attention, and limited data is present on the autecology of the species, in Campylodiscus scalaris an example which was described from the South African coasts, our findings in the Black Sea expanded the biogeographic range of the species in lower saline waters of the Black Sea. This could suggest that with the help of the ultrastructural view, more species could be introduced to the Black Sea flora and contribute to their habitats.

Marine benthic diatoms are important components of the coastal areas; nevertheless, low salinity levels could yield such challenging environments and could be suitable both for brackish and freshwater taxa to survive (Petrov \& Nevrova, 2007; Barinova et al., 2019). Recently benthic diatom communities in the Black Sea have become intensively studied in the north due to observing the diatoms' adaptation to environmental changes. On the other hand, Black Sea flora consisted mostly of the presented taxa, particularly in the Northern Black Sea (Petrov \& Nevrova, 2007; Nevrova \& Petrov, 2019) showed the high biodiversity presence of Bacillariaceae. Although diatom biodiversity of diatoms from the Turkish coasts has not been studied in depth before, some of the previous studies (Baytut \& Gönülol, 2016; Kaleli et al., 2017) devoted to benthic diatom flora found that biodiversity could be even higher than that which has been investigated so far on the Black Sea coasts. Also previously, freshwater taxa were reported from the coasts or lagoons in the Black Sea (Soylu et al. 2011; Kaleli \& Akçaalan, 2021 and references therein).

The current study represented some of the taxa with SEM. Although the ultrastructure of the valves is a more reliable way of identification, some taxa (C. thuretii, C. bicostatus, $R$. brebissonii) should be investigated further from the location. Due to the lack of specimens, some taxa could not be defined at the species level. Therefore, for those, there is a need to observe more valves in LM and SEM. Finally, ultrastructure analysis revealed that Nitzschia liebethruthii, N. volvendirostrata, Epithemia guettingeri and Campylodiscus scalaris were reported for the first time in the coastal waters of Turkey and contributed to the knowledge of marine benthic diatoms.

\section{CONCLUSION}

Eregli Bay, located on the southwestern coasts of the Black Sea, is a moderately populated industrial zone. The taxa discussed above contributed to the knowledge of Turkish diatom flora as well as the Black Sea. The characteristics of the Black Sea could allow a wide range of diatom communities in terms of habitat preference (Nevrova, 2016; Barinova et al., 2019). In addition to this, some studies in the coastal lakes and lagoons in the Turkish Black Sea coast indicated that the diatom community in these areas could be also composed of several freshwater forms (Soylu et al. 2010, 2011). This study brings comprehensive data on the marine and brackish forms which could grow on the hard substrates of the bays in the Southern Black Sea coasts. Further studies would provide data both for the taxonomical aspect and extend the biogeography of the taxa for the Black Sea. Even when the species are taken into consideration under family or order classification, the Turkish coasts of the Black Sea presented a high level of biodiversity, and this could be useful to understand the biodiversity of diatoms and provide data for further studies in the region.

\section{Conflict of Interest}

The authors declare no conflict of interest.

Ethics committee approval: Ethics committee approval is not required.

Financial disclosure: This study was supported by the Scientific Research Project Fund of Sivas Cumhuriyet University under project number STKMYO-007.

Acknowledgement: We thank anonymous reviewers for their comments which improved the manuscript. The authors thank Cüneyt Nadir Solak from Dumlupınar University for his contribution.

\section{REFERENCES}

Barinova, S., Bondarenko, A., Ryabushko, L. \& Kapranov, S. (2019). Microphytobenthos as an indicator of water quality and organic pollution in the western coastal zone of the Sea of Azov. Oceanological and Hydrobiological Studies, 48(2), 125-39. [CrossRef]

Baytut, Ö., Gönülol, A. \& Koray, T. (2005). New records for marine phytoplankton of Turkish Seas from Southern Black Sea coasts. E.U. Journal of Fisheries \& Aquatic Sciences, 22(1-2), 229-31. 
Baytut, Ö. \& Gönülol, A. (2016). Phytoplankton distribution and variation along a freshwater-marine transition zone (Kızllırmak River) in the Black Sea. Oceanological and Hydrobiological Studies, 45(4), 453-65. [CrossRef]

Blanco, I.A. \& Blanco, S. (2014). Benthic Diatoms from Mediterranean Coasts. Bibliotheca Diatomologica Vol 60. Schweizerbart Science Publishers, Stuttgart, 409 pp.

Çolak Sabancı, F. \& Koray, T. (2010). Four new records for the benthic diatoms (Genera Cocconeis, Seminavis, Synedra, and Trachysphenia) from the Aegean Sea. Turkish Journal of Botany, 34, 531-540.

English, J. \& Potapova, M. (2011). Surirella brebissonii. Diatoms of North America. Retrieved from https://diatoms.org/species/surirella_ brebissonii (accessed 24.04.2019).

Ersanlı, E. \& Gönülol, A. (2003). Study on the phytoplankton and seasonal variation of Lake Simenit (Terme-Samsun, Turkey). Turkish Journal of Fisheries and Aquatic Sciences, 3, 29-39.

Foged, N. (1975). Some Littoral Diatoms from the Coast of Tanzania. Bibliotheca Phycologica, 16, 1-127.

Giffen, M.H. (1967). Contributions to the diatom flora of South Africa III. Diatoms of the marine littoral regions at Kidd's Beach near East London, Cape Province, South Africa. Nova Hedwigia, 13, 245-292.

Guiry, M.D. \& Guiry, G.M. (2021). AlgaeBase. World-wide electronic publication, National University of Ireland, Galway. Retrieved from http://www.algaebase.org (Accessed 24.02.2021).

Hällfors, G. (2004). Checklist of Baltic Sea phytoplankton species. Baltic Sea Environmental Proceedings, 95, 1-208.

Hafner, D., Jasprica, N. \& Car, A. (2018). Taxonomic survey of benthic diatoms in Neum Bay, southeastern Adriatic. Natura Croatica, 27, 1-26. [CrossRef]

Hasle, G.R. \& Syvertsen, E.E. (1996). Marine Diatoms. In: Tomas, C.R. (Ed.) Identifying Marine Phytoplankton (p. 5-385). San Diego, Academic Press. [CrossRef]

Hendey, N.I. (1974). A revised checklist of the British marine diatoms. Journal of the Marine Biological Association of the United Kingdom, 54, 277-300. [CrossRef]

Hofmann, G., Werum, M. \& Lange-Bertalot, H. (2011). Diatomeen Im Süßwasser-Benthos von Mitteleuropa. A. R. G. Gantner Rugell, Pp. 908.

Hustedt, F. (1939). Die diatomeenflora des küstengebietes der Nordsee vom dollart bis zur elbemündung. I. Die diatomeenflora in den sedimenten der unteren ems sowie auf den watten in der Leybucht, des Memmert und bei der insel juist. Adhandlungen des Naturwissenschaftlichen Verein zu Bremen, 31, 571-677.

Hustedt, F. (1985). The Pennate Diatoms. A translation of Hustedt's "Die Kieselalgen, Teil 2", with supplement by Norman G. Jensen. Koenigstein, Germany, Koeltz Scientific Books, Pp. 918.

Kaleli, A., Kulikovskiy, M. \& Solak, C. (2017). Some new records for marine diatom flora of Turkey from Akliman, Sinop (Black Sea). Turkish Journal of Fisheries and Aquatic Sciences, 17, 1387-95. [CrossRef]

Kaleli, A., Kociolek, J. \& Solak, C.N. (2020). Taxonomy and distribution of diatoms on the Turkish Mediterranean coast, Dalyan (Muğla). Mediterranean Marine Science, 21, 201-215. [CrossRef]

Kaleli, A. \& Akçaalan, R. (2021). Checklist of marine diatoms from the Turkish coastal waters with updated nomenclature. Aquatic Research, 4(1), 88-115. [CrossRef]

Kociolek, J.P., Balasubramanian, K., Blanco, S., Coste, M., Ector, L., Liu, Y., et al. (2021). DiatomBase. Retrieved from www.Diatombase.org (Accessed 24.01.2021).

Krammer, K. (1988). The gibberula-group in the genus Rhopalodia O. Müller (Bacillariophyceae). II. Revision of the group and new taxa. Nova Hedwigia, 47(1-2), 159-205.

Krammer, K. \& Lange-Bertalot, H. (1987). Morphology and taxonomy of Surirella ovalis and related taxa. Diatom Research, 2, 77-95. [CrossRef]
Krammer, K. \& Lange-Bertalot, H. (1988). Bacillariophyceae: Teil 2: Bacillariaceae, Epithemiaceae, Surirellaceae. Süsswasserflora von Mitteleuropa, Band 2/2.

Kulikovskiy, M.S., Glushchenko, A.M., Genkal, S.I. \& Kuznetsova, I. (2016) Identification Book of Diatoms from Russia. Yaroslavl: Filigran, 804 $\mathrm{pp}$.

Lange-Bertalot, H. \& Krammer, K. (1987). Bacillariaceae, Epithemiaceae, Surirellaceae. Neue und wenig bekannte taxa, neue kombinationen und synonyme sowie bemerkungen und ergänzungen zu den Naviculaceae. Bibliotheca Diatomologica, 15(2), 1-289.

Legler, F. \& Krasske, G. (1940). Diatomeen aus dem Vannsee (Armenien). Beiträge zur ökologie der brackwasserdiatomeen I. Beihefte zum Botanischen Centralblatt, 60, 335-345.

Lee, J., McEnery, M., Kuile, B., Erez, J., Röttger, R., Rockwell, R., et al. (1989). Identification and distribution of endosymbiotic diatoms in larger foraminifera. Micropaleontology, 35(4), 353-366. [CrossRef]

Lobban, C.S., Schefter, M., Jordan, R.W., Arai, Y., Sasaki, A., et al. (2012). Coral-reef diatoms (Bacillariophyta) from Guam: new records and preliminary checklist, with emphasis on epiphytic species from farmer-fish territories. Micronesica, 43, 237-479.

Louvrou, I. (2007).Periphyton and its colonization in marine hydrothermal regions of island Milos (Greece). PhD. Thesis, University of Athens, Greece.

Maraşlıoğlu, F. \& Gönülol, A. (2021). Turkish Algae Electronic Publication. Retrieved from http://turkiyealgleri.hitit.edu.tr (Accessed 10.03.2021).

Mereschkowsky, C. (1902). Note sur quelques Diatomées de la Mer Noire. Journal de Botanique, 16, 319-324, 358-360, 416-430.

Navarro, J.N. (1982). Marine diatoms associated with mangrove prop roots in the Indian River, Florida, U.S.A. Bibliotheca Phycologica, 61, $1-151$.

Navarro, J.N. (1983). A survey of the marine diatoms of Puerto Rico. Botanica Marina, 26, 393-408. [CrossRef]

Navarro, J.N. \& Lobban, C.S. (2009). Freshwater and marine diatoms from the Western Pacific Islands of Yap and Guam, with notes on some diatoms in damselfish territories. Diatom Research, 24(1), 123-157. [CrossRef]

Nevrova, E. (2016). The composition and structure of the benthic diatom taxocene (Bacillariophyta) near Cape Fiolent (the Crimea, the Black Sea). Russian Journal of Marine Biology, 42(5), 392-401. [CrossRef]

Nevrova, E. \& Petrov, A. (2019). Benthic diatoms species richness at Dvuyakornaya Bay and other coastal sites of Crimea (the Black Sea) under various environments. Mediterranean Marine Science, 20(3), 506-520. [CrossRef]

Nevrova, E., Witkowski, A., Kulikovskiy, M., Lange-Bertalot, H. \& Kociolek, J.P. (2013). A revision of the diatom genus Lyrella Karayeva (Bacillariophyta: Lyrellaceae) from the Black Sea, with descriptions of five new species. Phytotaxa, 83(1), 1-38. [CrossRef]

Park, J.S., Lobban, C.S. \& Lee, K.W. (2018). Diatoms associated with seaweeds from Moen Island in Chuuk Lagoon, Micronesia. Phytotaxa, 351(2), 101-40. [CrossRef]

Peragallo, H. \& Peragallo, M. (1897-1908). Diatomees marines de France et des district maritimes voisins. M.J. Tempere, Grez-sur-Loing, Pp. 491. [CrossRef]

Petrov, A. \& Nevrova, E. (2007). Database on Black Sea benthic diatoms (Bacillariophyta): its use for a comparative study of diversity pecularities under technogenic pollution impacts. In: Vanden Berghe, E. (Ed.) Proceedings Ocean Biodiversity Informatics: International Conference on Marine Biodiversity Data Management, Hamburg, Germany 29 November to 1 December, 2004. VLIZ Special Publication, Pp. 37

Petrov, A., Nevrova, E., Terletskaya, A., Milyukin, M. \& Demchenko, V. (2010). Structure and taxonomic diversity of benthic diatom assemblage in a polluted marine environment (Balaklava Bay, Black Sea). Polish Botanical Journal, 55(1), 183-97. 
Poulin, M., Bérard-Therriault, L., Cardinal, A. \& Hamilton, P.B. (1990). Les diatomées (Bacillariophyta) benthiques de substrats durs des eaux marines et Saumâtres du Québec. 9. Bacillariaceae. Le Naturaliste Canadien, 117(2), 73-101.

Proshkina-Lavrenko A.I. (1955). Диатомовые водоросли планктона Черного моря. Москва-Ленинград. АН СССР. [Planktonic diatoms of the Black Sea. Moscow-Leningrad, AS USSR. (in Russian)].

Proshkina-Lavrenko A.I. (1963). Диатомовые водоросли бентоса Черного моря. Москва-Ленинград. АН СССР. [Benthic diatoms of the Black Sea. Moscow-Leningrad, AS USSR (in Russian)].

Reimer, C.W. \& Lee, J.J. (1984). A new pennate diatom: Protokeelia hottingeri gen. et sp. nov. Proceedings of the Academy of Natural Sciences of Philadelphia, 136, 194-199.

Romagnoli, T., Totti, C., Accoroni, S., De Stefano, M. \& Pennesi, C. (2014). SEM analysis of the epibenthic diatoms on Eudendrium racemosum (Hydrozoa) from the Mediterranean Sea. Turkish Journal of Botany, 38, 1-29. [CrossRef]

Round, F.E. \& Basson, P.W. (1995a). The transference of Auricula cholnokyi Giffen and A. quinquelobata Voigt to Protokeelia. Diatom Research, 10(1), 211-215. [CrossRef]

Round, F.E. \& Basson, P.W. (1995b). Protokeelia aculeata nov. sp. from Bahrain. Diatom Research, 10(2), 333-339. [CrossRef]

Rovira, L., Trabajo, R., Sato, S., Ibáñez, C. \& Mann, D.G. (2015). Genetic and physiological diversity in the diatom Nitzschia inconspicua. Journal of Eukaryotic Microbiology, 62, 815-832. [CrossRef]

Ruck, E.C., Nakov, T., Alverson, A.J. \& Theriot, E.C. (2016). Phylogeny, ecology, morphological evolution, and reclassification of the diatom orders Surirellales and Rhopalodiales. Molecular Phylogenetics and Evolution, 103, 155-171. [CrossRef]

Salleh, S. \& McMinn, A. (2011). The effects of temperature on the photosynthetic parameters and recovery of two temperate benthic microalgae, Amphora cf. coffeaeformis and Cocconeis cf. sublittoralis (Bacillariophyceae). Journal of Phycology, 47(6), 1413-1424. [CrossRef]

Schmidt, A. (1874-1959). Atlas der Diatomaceen-kunde, Vol 1-120. R. Reisland, Ascherleben, Leipzig. [CrossRef]

Snigireva, A.A. \& Kovaleva, G.V. (2015). Diatom algae of sandy spits of the Northwestern Part of the Black Sea (Ukraine). International Journal on Algae, 17(2), 107-130. [CrossRef]

Snoeijs, P. \& Potapova, M. (1995). Intercalibration and distribution of diatom species in the Baltic Sea, Volume 3, The Baltic Marine Biologist Publication, 16c. 126 pp. Opulus Press, Uppsala.

Snoeijs, P. \& Balashova, N. (1998). Intercalibration and Distribution of Diatom Species in the Baltic Sea, Vol. 5, The Baltic Marine Biologist Publication, 16e, Uppsala, Opulus Press, Pp. 144.
Soylu, E.F., Maraşlıoğlu, F. \& Gönülol, A. (2011). Epipelic algae and seasonal variation of Gıcı Lake (Samsun, Bafra). Journal of Fisheries. com, 4(4), 437-445. [CrossRef]

Soylu, E.N., Maraşlıoğlu, F. Gönülol, A. (2011). Epiphytic diatom flora of Liman Lake (Bafra-Samsun). Ekoloji, 20, 57-62.

Suzuki, H., Nagumo, T. \& Tanaka, J. (2010). Nitzschia amabilis nom. nov., a new name for the marine species $N$. laevis Hustedt. Diatom Research, 25(1), 223-224. [CrossRef]

Vilbaste, S., Sundback, K., Nilsson, C. \& Truu, J. (2000). Distribution of benthic diatoms in the littoral zone of the Gulf of Riga, the Baltic Sea. European Journal of Phycology, 35(4), 373-85. [CrossRef]

Witkowski, A. (1991). Diatoms of the Puck Bay coastal shallows (Poland, Southern Baltic). Nordic Journal of Botany, 11(6), 689-701. [CrossRef]

Witkowski, A. (1994). Recent and Fossil Diatom Flora of the Gulf of Gdansk, Southern Baltic Sea: Origin, Composition and Changes of Diatom Assemblages during the Holocene. Bibliotheca Diatomologica 28. Berlin, J. Cramer, 313 pp.

Witkowski, A., Lange-Bertalot, H. \& Metzeltin, D. (2000). Diatom Flora of Marine Coasts I. In: Lange-Bertalot H. (Ed.) Iconographia Diatomologica 7. Konigstein: Koeltz Scientific Books. 895 pp.

Witkowski, A., Kociolek, J.P. \& Wawrzyniak-Wydrowska, B. (2004). Four new species of Nitzschia sect. Tryblionella (Bacillariophyceae) resembling N. parvula. Phycologia, 43(5), 579-95. [CrossRef]

Witkowski, A., Kulikovskiy, M., Nevrova, E., Lange-Bertalot, H. \& Gogorev, R. (2010). The genus Navicula in ancient basins. I. two novelties from the Black Sea. Plant Ecology and Evolution, 143(3), 307-17. [CrossRef]

Witkowski, J., Bohaty, S.M., Edgar, K.M. \& Harwood, D.M. (2014). Rapid fluctuations in mid-latitude siliceous plankton production during the middle Eocene climatic optimum (ODP site 1051, Western North Atlantic). Marine Micropaleontology, 106, 110-129. [CrossRef]

Witkowski, A., Li, C., Zgłobicka, I., Yu, S., Ashworth, M., et al. (2016). Multigene assessment of biodiversity of diatom (Bacillariophyceae) assemblages from the littoral zone of the Bohai and Yellow Seas in Yantai Region of Northeast China with some remarks on ubiquitous Taxa. Journal of Coastal Research, 74, 166-95. [CrossRef]

Witon, E. \& Witkowski, A. (2006). Holocene diatoms (Bacillariophyceae) from Faroe Islands Fjords, Northern Atlantic Ocean. II. Distribution and taxonomy of marine taxa with special reference to benthic forms. Diatom Research, 21(1), 175-215. [CrossRef]

Yıldız, A. (2018). A Taxonomical Investigation on the Marine Benthic Diatom Flora of Dardanel Strait (In Turkish). Master Thesis. Kütahya, Turkey, 86pp. 